\title{
Effects of Food Wastes on Yellow Mealworm Tenebriomolitor Larval Nutritional Profiles and Growth Performances
}

\author{
Shu Wei Tan ${ }^{1}$, Kok Song Lai ${ }^{2}$ and Jiun Yan Loh ${ }^{1 *}$ \\ ${ }^{1}$ Faculty of Applied Sciences, UCSI University, Malaysia \\ ${ }^{2}$ Department of Cell and Molecular Biology, Universiti Putra Malaysia, Malaysia
}

*Corresponding author: Jiun Yan Loh, Functional Food Research Group, Faculty of Applied Sciences, UCSI University. No. 1, Jalan Menara Gading, UCSI Heights, 56000, Kuala Lumpur, Malaysia, Fax: 60391023606; Tel: 60391018880; Email: lohjy@ucsiuniversity.edu.my

Submission: 眥 May 08, 2018 ; Published: 眥June 11, 2018

\begin{abstract}
In this study, nutritional profiles and growth performances of yellow mealworm, Tenebriomolitor larvae (TML) were assessed cultivated using common food wastes i.e. watermelon rinds, broilers' eggshells and banana peels. Nutritional profiles and growth performance of TML were evaluated after 28-day feeding trial. Post-feeding proximate analysis showed significant increment of nutritional contents compared to the control groups; whereby TML demonstrated highest level of crude protein $(43.38 \% \pm 2.71)$, moisture $(9.74 \% \pm 0.23)$ and ash $(4.40 \% \pm 0.22)$ in the group treated with watermelon wastes. On the other hand, TML showed highest level of crude fibre $(8.73 \% \pm 0.05)$ when treated with broilers' eggshells; and higher level of crude fat $(40.13 \% \pm 4.66)$ with banana wastes. Nitrogen-free extract (NFE) contents were also noticed higher in the group treated with banana wastes $(4.46 \% \pm 5.30)$. In terms of growth performance, TML administrated with watermelon wastes demonstrated superior in specific growth rate $(2.50 \% \pm 0.43)$ and feed conversion efficiency $(0.10 \% \pm 0.01)$. Interestingly, TML grown with banana wastes showed highest survival rate $(97.5 \%)$ among all. In short, TML cultivation using watermelon and banana wastes showed a promising result on nutritional fortification and growth enhancement.
\end{abstract}

Keywords: Food waste; Proximate analysis; Specific growth rate; Survival rate; Tenebriomolitor

\section{Introduction}

Aquaculture is the fastest growing food-producing sector $[1,2]$. According to FAO [3] global total fisheries production reached to 167.2 million tonnes in 2014, with 93.4 million tonnes from capture, and 73.8 million tonnes production from aquaculture. Fish pellet is common used to fulfil diet/nutritional requirement of cultured species in semi intensive and intensive farming practices. However, fishmeal as a major ingredient in fish pellet, facing a great pressure due to inconsistency of by-catch supply. Yet, market price of raw fishmeal is fluctuating seasonally depends on geographical location, fishing technology and availability of fish stock [4-6]. Fishmeal is processed from by-catch or trash fish. Trash fish production in Asian continents encompasses $13-90 \%$ of total fishery landings $[6,7]$ the major utilization of these by-catches are primary for animal feeding. Extracting wild stock for feeding farmed fish is no longer a sustainable practice for aquaculture due to depletion of fishery resources, and the availability of trash fish as a direct feed ingredient is likely to restrict the further expansion of aquaculture industry [5]. Furthermore, trash fish serves an excellent medium for bacterial or viral disease transmission. Diseases such as viral nervous necrosis (VNN) infection and Vibrio harvevi [8] are high infectious to countless of fish farms.
Trash fish is also the main problem of parasitic infestation which contributes to significant economic losses in mariculture [5,7,9-11]. Hence, alternative protein resource such as insect-based ingredient is highly sought after for substitution of fishmeal in feed formulation. The use of insect-based diet in animal farming is able to help in mitigating environmental impact especially the sustainability of fishery wild stock as compared to fishmeal production [7]. EU Commission Regulation 2017/893 is permitting the use of insect-based protein for sustainable aquaculture commencing from 2017 [11]. Insects such as black soldier fly larvae, maggot, mealworm, house cricket and grasshopper offer a valuable and more sustainable alternative to fishmeal as key ingredients in animal feeds. These insects are not only rich in protein but also abundant in various nutritional contents such as fats and macronutrients.

For instance, mealworms tenebriomolitorare often produced commercially as feed items or supplementation for ornamental fish, birds, reptiles and small mammals. In terms of cultivation, mealworms production required little management and less laborious skills. Furthermore, they are highly efficient in converting 
food wastes and agricultural by-products into quality biomass. The biomass could be a potential feedstuff to replace fishmeal in diet formulation. Insect-based protein offers a promising alternative to fishmeal as ingredients in fish feed for aquaculture [12-14]. The scale-up, automation and energy optimization in mealworm production industry, however, is required to reduce production costs and to make insect meals more feasible from an economic point of view. Therefore, the present study was aimed to investigate the effects of several food wastes on nutritional fortification and growth performance of T. Molitor larvae (TML). Common kitchen food wastes such as by-products of banana (peels), watermelon (rinds) and broiler's eggshells were selected in the study because of their local availability (non-seasonal), abundance and nutritional contents. Nutritional composition and growth performances of TML were determined to elucidate the effects of different food wastes on the mealworm cultivation [15].

\section{Material and Methods}

Diet preparation: Rinds of watermelon Citrulluslanatus (Diet 1), broilers' eggshells (Diet 2), peels of banana Musa acuminate (Diet 3), mixture of diets 1, 2 and 3 with ratio of 1:1:1 (Diet 4) were oven dried at $70^{\circ} \mathrm{C}$ for 24 hours. Commercial white bread (Gardenia Bakeries (KL) Sdn. Bhd.) as a control diet was oven dried at $120^{\circ} \mathrm{C}$ for 15 minutes. All diets were ground into fine powder particles, and kept at room temperature until use.

Feeding trial and experimental design: Approximately 6,750 yellow mealworms, Tenebriomolitor larvae (TML, at 1-2 month/s old) were obtained from an aquarium (Ninety Nine Fish \& Pets Sdn. Bhd., Taman Taynton Cheras, Kuala Lumpur, Malaysia). The TML were distributed in 15 plastic containers $(30 \times 15 \times 5 \mathrm{~cm}$; W $\times \mathrm{L} \times \mathrm{H})$ with 450 larvae in each. The mealworm cultivation setup was located under a shaded corner $\left(25^{\circ} \mathrm{C} \pm 1\right)$ to avoid direct sunlight (light: dark; 12h: 12h). Prior to the feeding, TML were starved for 24 hours to reduce gut contents. During the feeding trial, $20 \mathrm{~g}$ of respective Diet 1,2,3,4 and a control were administrated to five different groups of TML; feeding was given once in a week. Moist cotton pads were provided to maintain humidity in the containers, and the pads were replaced daily for hygiene purpose [15]. After 28 day of feeding period, TML were collected from respective diet groups and boiled $\left(100{ }^{\circ} \mathrm{C}\right)$ for 3 minutes, and then oven dried at $60{ }^{\circ} \mathrm{C}$ for 24 hours [16]. After drying process, meal worm carcasses were collected and ground into fine particles using an electric blender at maximum speed (Sharp, Japan) prior to the nutritional analysis. Three replicates were performed for each diet group in the experiment.

Nutritional analysis of tenebriomolitor: Crude protein content of TML sample was determined through digestion with Kjeldahl's method [17]. Kjeldahl factor was set at 6.25 for each sample [18]. The moisture content was analysed by oven drying method at $105{ }^{\circ} \mathrm{C}$ for 3 hours; ash determination by incinerating in a furnace at $550{ }^{\circ} \mathrm{C}$ for 16 hours [17]. Crude fat content of the samples was determined by consecutive extraction using Soxhlet method. While crude fibre was determined by subsequent hot digestion of defatted samples using $0.128 \mathrm{M}$ sulphuric acid and $1.25 \%(\mathrm{w} / \mathrm{v}$ ) sodium hydroxide [17]. Nitrogen-free extract (NFE) of the samples was calculated by subtraction [17]. All analysis was performed in triplication.

Evaluation of growth performance and survival of tenebriomolitor: Feed conversion, growth performance and survival of 20TML in each treatment group were determined after feeding trial. Performance in growth and feed utilisation were determined based on the criteria: length gain (LG), weight gain (WG), specific growth rate (SGR), feed conversion ratio (FCR) and feed conversion efficiency (FCE) [19,20]. Calculation of each criterion was done based on the formulas below:

a. $\quad L G(\%)=100[($ Final length-Initial length)/Initial length].

b. $W G(\%)=100[($ Final weight- Initial weigh)/Initial weight $]$.

c. SGR (\%) $=100[($ ln Final weight)-(ln Initial weight) /total feeding days].

d. $\quad$ FCR $(\mathrm{kg} / \mathrm{kg})=$ Weight of diet/Weight of mealworms gained .

e. FCE $(\%)=100$ (Weight of mealworms gained/Weight of diet).

f. Survival rate $(\%)=100$ (Initial population-Number of dead mealworms)/Initial population.

4.5. Statistical analysis: Statistical analyses were conducted using SPSS Statistical Package. Data were subjected to one-way ANOVA analysis and Post hoc analysis using Tukey's Multiple Comparison Test (Tukey's test) to evaluate differences between groups with the acceptance at $\mathrm{p}<0.05$.

\section{Results}

\section{Nutritional profiles of tenebriomolitor}

Mealworms T. Molitor larvae (TML) fed on Diet 1 showed the highest crude protein $(43.38 \% \pm 2.71)$ while the lowest protein level $(38.53 \% \pm 1.43)$ was found in TML fed on Diet 3 (Table 1). Generally, the crude protein content of larvae fed on the five diets did not significantly differ from each other (ANOVA; $F=1.49$, $\mathrm{p}=0.26$ ). In terms of moisture content, the highest moisture content (9.74\% \pm 0.23$)$ was found in TML tissues administrated with Diet 1 , and the lowest moisture content $(8.06 \% \pm 0.55)$ was recorded when mealworm treated with control diet (commercial breadGardenia ${ }^{\circledR}$ ) (ANOVA; $F=13.42, p=0.00$ ). Among the treatments, TML administrated with Diet 1 showed the highest ash content $(4.40 \% \pm 0.22)$ while TML grew on control diet displayed lowest level of ash content $(1.87 \% \pm 0.49)$ (Table 1$)$. Values with different letters in the same column are significantly different $(p<0.05)$ among the nutrients $(n=3)$.

Highest crude fat content was found in the muscle of TML in control group $(40.13 \% \pm 1.63)$ and those treated with Diet 3 (40.13\% \pm 4.66$)$. Analysis showed that TML administrated with Diet 4 recorded at $33.92 \% \pm 2.05$; Diet 2 at $33.57 \% \pm 3.69$ and the least with Diet 1 at $32.84 \% \pm 4.14$, respectively. However, no 
significant difference was noticed among the dietary treatment. In overall, TML administrated with Diet 2 showed the highest crude fibre content $(8.73 \% \pm 0.05)$, followed by Diet $4(8.18 \% \pm 0.35)$, control diet $(6.75 \% \pm 0.64)$, Diet $1(6.48 \% \pm 1.40)$ and the lowest with Diet $3(6.27 \% \pm 0.09)$ (ANOVA; $F=6.77, p=0.00)$ (Table 1). In terms of NFE, TML administrated with Diet 3 showed the highest value $(4.46 \% \pm 5.30)$ in contrast, control group marked the least $(1.69 \% \pm 4.79)$. Nevertheless, no significant difference was found among these diet groups with regard on NFE (ANOVA; $F=0.133$, $\mathrm{p}=0.98)$.

\section{Growth performance of Tenebriomonitor}

Both the growth performance and feed conversion of TML were summarised in (Table 2). TML fed on Diet 1 showed longest body's length (LG) gain $(22.17 \% \pm 2.16)$, followed by Diet $3(21.03 \% \pm 1.95)$, the control diet $(18.30 \% \pm 5.95)$, Diet $4(14.25 \% \pm 1.18)$ and $2(13.90 \% \pm 2.91)$, despite no significant different among the treatments ( $p>0.05$ ) (Table 2). Likewise, similar trend was noticed on the weight-gained (WG) and specific growth rate (SGR); whereby Diet 1 showed the highest WG at $102.26 \% \pm 23.27$; SGR at $2.50 \% \pm 0.43$ and the lowest found with Diet 2 at $64.76 \% \pm 16.10$ (WG) and $1.77 \% \pm 0.34$ (SGR), respectively. In terms of biomass conversion, TML fed on Diet 2 showed the highest feed conversion ratio (FCR) (4.31 \pm 0.95$)$ among all. On the other hand, TML treated with Diet 1 showed the lowest FCR $(2.66 \pm 0.23)$ (Table 2). However, these results showed only TML fed on Diet $2(4.31 \pm 0.95)$ showed the significant difference compared to control (ANOVA; $F=5.74$, $\mathrm{p}=0.01$ ), not for those with Diet 1, 3 and 4 (Table 2). Values with different letters in the same column were significantly different ( $\mathrm{p}<0.05)$; Parameters were determined based on the mealworms T. Molitor survivors per treatment ( $\mathrm{n}=20$ /treatment). LG denotes length gain; $\mathrm{WG}=$ weigh gain; $\mathrm{SGR}=$ specific growth rate; $\mathrm{FCR}=$ food conversion ratio and $\mathrm{FCE}=$ food conversion efficiency. All data in percentage (\%) calculated based on initial measurement.

Results also revealed TML treated on Diet 1 showed the highest feed conversion efficiency (FCE) $(0.10 \% \pm 0.01)$ among the five treatment groups (Table 2). Only TML fed on Diet 2 was differed significantly than others (ANOVA; $F=6.93, p=0.01$ ) (Table 2). It is interesting to note that, Diet 3 showed the highest survival rate $(97.5 \%)$ followed by Diet $1(95.0 \%), 4(94.6 \%)$, control diet (90.4\%) and 2 (86.4\%) (Figure 1). Overall, Diet 1 showed better results in terms of nutrients e.g. crude protein, moisture, ash and crude fat. The growth performance and FCE were highest using Diet 1 as well. When Diet 3 was used, it showed highest survival rate in TML cultivation.

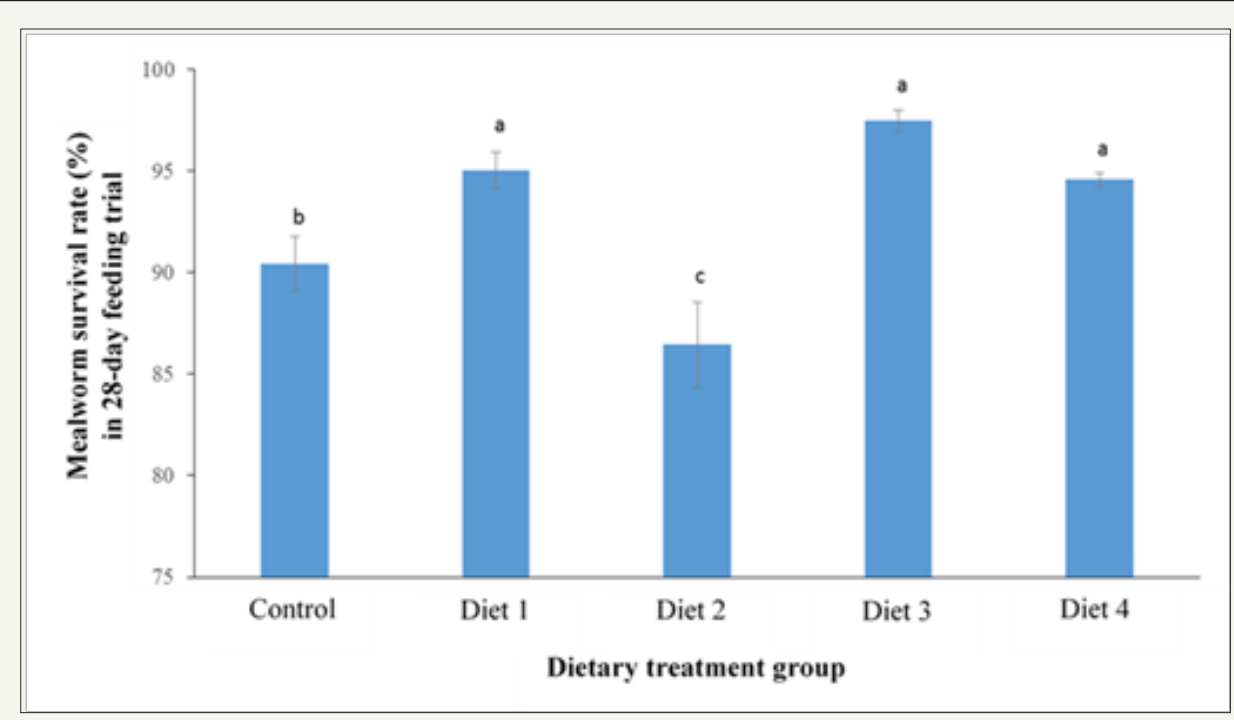

Figure 1: The survival rate (\%) of mealworms T.molitorfed on different diets (Control: bread - Gardenia ${ }^{\circledR}$; Diet 1: watermelon rinds; Diet 2: eggshells; Diet 3: banana peels; Diet 4: mixture of Diet 1 - 4). Mean values with same letters within dietary treatments $(n=3)$ are not significantly different (HSD0.05). Vertical bars indicate standard deviation of means.

\section{Discussion}

Crude protein content of TML was slightly lower in present study compared to commercial oat flakes (44.72\%) and wheat bran (46.44\%) as reported by Ravzanaadii et al. [21] and Siemianowska et al. [16]. Among all, Diet 1 (crude protein: 11.57\%; crude fat: $11.74 \%$ and NFE: $21.28 \%$ ) demonstrated greatest efficiency in terms of growth performance of TML (Table 2). Morales Ramos et al. [15] reported diet with high crude protein $(155 \mathrm{mg} / \mathrm{g})$ and crude fat $(43 \mathrm{mg} / \mathrm{g}$ ) could produce longest TML at the 14 th instar's stage. In terms of FCR, Diet 2 showed the lowest amount of crude protein and relatively higher FCR when feeding was provided to TML, Diet 3 showed slightly increase of FCR; while the lowest FCR was observed using Diet 1 (Table 1 \& 2). In fact, FCR always associated to the protein content in diet. Higher protein content helps in muscle development, and thus lowering FCR; and vice versa [22].

According to Huis [23], TML fed on plant-based waste materials contained low fat contents. In contrast to the finding, our study showed TML has higher fat contents when treated with fruit wastes (40.13\%using banana peels;32.84\% using watermelon rinds) (Table 1), which is also slightly higher than wheat bran $(32.70 \%)$ 
reported previously [21]. Siemianowska et al. [16] showed that worm-meal contained 50.05\% unsaturated oleic acid (C18:1n9), 23\% palmitoleic acid (C16:0) and 10.97\% linoleic acid (C18:2n6), of total lipid. High crude fat contents are of particular importance to fish and shellfish cultivation as only sufficient amount of unsaturated fatty acids (mono unsaturated and polyunsaturated) present in feedstuff could allow proper digestion of saturated fatty acids to meet the dietary requirements of cultured species [24]. Bio converting agricultural wastes into usable biomass is sustainable ways to produce food sources for domestic animal consumption. Abel et al. [25] and Siyal et al. [26] claimed banana peels could be recycled and reused for broiler chickens diet. Our result showed that TML reached to $0.09 \%$ increment in terms of FCR when banana peel was used as sole feeding material.
Mealworm is not only a potential insect-based diet to aquaculture but also as the emerging protein source for many terrestrial farmed animals e.g. chicken, poultry, swine and ruminants. As claimed by many studies, our finding also suggested that TML a good source of protein, this could in turn, benefiting the cultured species by enhancing their growth and survivorship [22]. Similar to black soldier fly (Hermetiaillucens), TML prefers plant-based diets [27]. It is capable to bio-convert waste materials to reusable energy with higher efficiency. When TML cultivated with dietary fibre such as roughages, it showed better growth performance compared to wheat middling or Distillers Dried Grains with Soluble (DDGS). This also clearly shown in our study in particularly the growth rate was among the highest when TML treated with Diet 2 (high crude fibre) (Table 1).

Table 1: Nutritional compositions of mealworms tenebriomolitor.

\begin{tabular}{|c|c|c|c|c|c|c|}
\hline \multirow{2}{*}{$\begin{array}{l}\text { Mealworms } T \text {. } \\
\text { molitor Fed on } \\
\text { Different Diets }\end{array}$} & \multicolumn{6}{|c|}{ Proximate Compositions (\%) } \\
\hline & Crude Protein & Moisture & Ash & Crude Fat & Crude Fibre & $\begin{array}{l}\text { Nitrogen-free } \\
\text { Extract (NFE) }\end{array}$ \\
\hline $\begin{array}{l}\text { Control diet: Bread } \\
\text { (Gardenia }(\circledR)\end{array}$ & $41.51 \pm 4.55^{\mathrm{a}}$ & $8.06 \pm 0.55^{c}$ & $1.87 \pm 0.49^{c}$ & $40.13 \pm 1.63^{\mathrm{a}}$ & $6.75 \pm 0.64^{\mathrm{bc}}$ & $1.69 \pm 4.79^{\mathrm{a}}$ \\
\hline $\begin{array}{l}\text { Diet 1: Watermelon } \\
\text { rinds }\end{array}$ & $43.38 \pm 2.71^{\mathrm{a}}$ & $9.74 \pm 0.23^{\mathrm{a}}$ & $4.40 \pm 0.22^{\mathrm{a}}$ & $32.84 \pm 4.14^{\mathrm{a}}$ & $6.48 \pm 1.40^{\mathrm{bc}}$ & $3.17 \pm 5.80^{\mathrm{a}}$ \\
\hline $\begin{array}{l}\text { Diet 2: Broiler's } \\
\text { eggshells }\end{array}$ & $42.49 \pm 2.28^{\mathrm{a}}$ & $9.55 \pm 0.35^{\mathrm{ab}}$ & $3.44 \pm 0.44^{\mathrm{ab}}$ & $33.57 \pm 3.69^{\mathrm{a}}$ & $8.73 \pm 0.05^{\mathrm{a}}$ & $2.23 \pm 6.02^{\mathrm{a}}$ \\
\hline $\begin{array}{l}\text { Diet 3: Banana } \\
\text { peels }\end{array}$ & $38.53 \pm 1.43^{\mathrm{a}}$ & $8.13 \pm 0.12^{c}$ & $2.48 \pm 0.88^{\mathrm{bc}}$ & $40.13 \pm 4.66^{\mathrm{a}}$ & $6.27 \pm 0.09^{c}$ & $4.46 \pm 5.30^{\mathrm{a}}$ \\
\hline $\begin{array}{l}\text { Diet 4: Mixture of } \\
\text { Diets 1, } 2 \text { and } 3\end{array}$ & $42.78 \pm 1.89^{\mathrm{a}}$ & $8.48 \pm 0.38^{c}$ & $3.62 \pm 0.24^{\mathrm{ab}}$ & $33.92 \pm 2.05^{\mathrm{a}}$ & $8.18 \pm 0.35^{\mathrm{ab}}$ & $3.02 \pm 1.07^{\mathrm{a}}$ \\
\hline
\end{tabular}

Table 2: The growth performance of meal worms tenebriomolitor throughout 28-day feeding trial.

\begin{tabular}{|c|c|c|c|c|c|}
\hline $\begin{array}{c}\text { Mealworms T. molitor } \\
\text { Fed on Different } \\
\text { Diets }\end{array}$ & LG (\%) & WG (\%) & SGR (\%) & FCR $(\mathrm{kg} / \mathrm{kg})$ & FCE (\%) \\
\hline $\begin{array}{l}\text { Control diet: Bread } \\
\text { (Gardenia } 囚)\end{array}$ & $18.30 \pm 5.95^{\mathrm{a}}$ & $90.67 \pm 3.73^{a}$ & $2.30 \pm 0.07^{\mathrm{a}}$ & $2.91 \pm 0.28^{\mathrm{a}}$ & $0.09 \pm 0.01^{\mathrm{ab}}$ \\
\hline $\begin{array}{l}\text { Diet 1: Watermelon } \\
\text { rinds }\end{array}$ & $22.17 \pm 2.16^{\mathrm{a}}$ & $102.26 \pm 23.27^{a}$ & $2.50 \pm 0.43^{\mathrm{a}}$ & $2.66 \pm 0.23^{\mathrm{a}}$ & $0.10 \pm 0.01^{\mathrm{a}}$ \\
\hline $\begin{array}{l}\text { Diet 2: Broiler's } \\
\text { eggshells }\end{array}$ & $13.90 \pm 2.91^{\mathrm{a}}$ & $64.76 \pm 16.10^{\mathrm{a}}$ & $1.77 \pm 0.34^{\mathrm{a}}$ & $4.31 \pm 0.95^{\mathrm{b}}$ & $0.07 \pm 0.01^{b}$ \\
\hline Diet 3: Banana peels & $21.03 \pm 1.95^{\mathrm{a}}$ & $101.38 \pm 15.30^{a}$ & $2.49 \pm 0.27^{\mathrm{a}}$ & $2.68 \pm 0.12^{\mathrm{a}}$ & $0.09 \pm 0.00^{\mathrm{a}}$ \\
\hline $\begin{array}{l}\text { Diet 4: Mixture of Diets } \\
\qquad 1,2 \text { and } 3\end{array}$ & $14.25 \pm 1.18^{\mathrm{a}}$ & $78.62 \pm 9.10^{\mathrm{a}}$ & $2.07 \pm 0.18^{\mathrm{a}}$ & $3.42 \pm 0.32^{\mathrm{ab}}$ & $0.08 \pm 0.01^{\mathrm{ab}}$ \\
\hline
\end{tabular}

The major problem facing by animal production industry is the source of protein [28]. To overcome this issue, alternative source of protein is therefore upmost important to reduce the reliant on animal source of protein such as fishmeal. Insect-based diet provides high content in various nutrients such as sulphur-containing-amino acids and highly unsaturated fatty acids, which could be potentially used as major feed ingredients [27]. According to $\mathrm{Ng}$ et al. [13], African catfish, Clariasgariepinus displayed similar growth and feed utilization efficiency as in fishmeal when their diet was replaced by $80 \%$ worm meal. A recent study also demonstrated that partial or complete replacement (up to $100 \%$ ) of TML in pacific white shrimp (Litopenaeusvannamei) diet, did not show any significant differences in terms of weight gain, specific growth rate, feed intake and feed conversion efficiency with fishmeal-treated group [14]. Inclusion of TML in the fish diet could also significantly improve protein efficiency and specific growth rate during the growing phase in rainbow trout (Oncorhynchusmykiss) farming. The inclusion of worm meal in the trout diets significantly decreased the relative fat quantity but $\Sigma$ C18:1 and C18:2 n6 increased with increment of the amount of worm meal in diet supplementation [13]. However, further research on nutritional value of the lipid fraction of trout fillets is needed in diet formulations. 


\section{Conclusion}

Our study concluded TML treated banana wastes showed significant improvement in the survival rate of TML. In terms of growth performance and nutritional improvement, watermelon wastes serve as the better option. Our study suggested TML farming could be scale-up and optimized using the agricultural wastes as presented here. The dataset provides a guideline for mealworm mass cultivation with more efficient and cost-saving manner.

\section{Acknowledgement}

The study was financially supported by the URP and UCSI CERVIE PSIF Grant (Proj-in-FAS-031).

\section{References}

1. FAO (2014) The state of world fisheries and aquaculture. Rome, Italy, p. 223.

2. SEAFDEC (2017) Report of the forty-ninth meeting of the council of the south East Asian fisheries development centre. Southeast Asian Fisheries Development Centre, Bangkok, Thailand, p. 295.

3. FAO (2016) The state of world fisheries and aquaculture. Contributing to food security and nutrition for all, Rome, Italy, p. 200.

4. Miles RD, Chapman FA (2006) The benefits of fish meal in aquaculture diets. Institute of Food and Agricultural Sciences, University of Florida, USA.

5. Huntington TC, Hasan MR (2009) Fish as feed inputs for aquaculturepractices, sustainability and implications: a global synthesis. In: Hasan MR, Halwart M (Eds.), Fish as feed inputs for aquaculture: practices, sustainability and implications. FAO Fisheries and Aquaculture Technical Paper 518: 1-61.

6. Jackson A (2009) The continuing demand for sustainable fishmeal and fish oil in aquaculture diets. International Aquafeed, pp. 28-32.

7. Simon FS, Lindebo E, Staples D (2005) Asian fisheries today: The production and use of low value/trash fish from marine fisheries in the Asia-Pacific region. Food and Agriculture Organization of the United Nations, Bangkok, Thailand.

8. Saravanan K, Nilavan SE, Sudhagar SA, Naveenchandru V (2012) Diseases of mariculture finfish species: A review. The Israeli Journal of Aquaculture Bamidgeh 65: 1-14.

9. Nagasawa K, Cruz Lacierda ER (2004) Diseases of cultured groupers Southeast Asian Fisheries Development Center, Iloilo, Philippines, Asia, p. 81.

10. Shakouri B, Yazdi SK (2012) The sustainable marine aquaculture. Advances in Environmental Biology 6(1): 18-23.

11. European Commission (2017) Amending Annexes I and IV to Regulation (EC) No 999/2001 of the European Parliament and of the Council and Annexes X, XIV and XV to Commission Regulation (EU) No 142/2011 as regards the provisions on processed animal protein. Commission Regulation (EU).

12. Ng WK, Liew FL, Ang LP, Wong KW (2002) Potential of mealworm (Tenebriomolitor) as an alternative protein source in practical diets for African catfish, Clariasgariepinus. Aquaculture Research 32(1): 273280.
13. Marco B, Gai F, Lussiana C, Renna M, Malfatto V, et al. (2015) Tenebriomolitor meal in rainbow trout (oncorhynchusmykiss) diets: effects on animal performance, nutrient digestibility and chemical composition of fillets. Italian Journal of Animal Science 14(4): 4170.

14. Panini RL, Pinto SS, Nóbrega RO, Vieira FN, Fracalossi DM, et al. (2017) Effects of dietary replacement of fishmeal by mealworm meal on muscle quality of farmed shrimp Litopenaeusvannamei. Food Research International 102: 445-450.

15. Morales Ramos JA, Rojas MG, Kay S, Shapiro Ilan DI, Tedders WL (2012) Impact of adult weight, density, and age on reproduction of Tenebriomolitor (Coleoptera: Tenebrionidae). Journal of Entomological Science 47(3): 208-220.

16. Siemianowska E, Kosewska A, Aljewicz M, Skibniewska KA, Juszczak P, et al. (2013) Larvae of mealworm (Tenebriomolitor L.) as European novel food. Agricultural Sciences 4(6): 287-291.

17. AOAC (2000) Official methods of analysis of AOAC International. $\left(17^{\text {th }}\right.$ edn), AOAC International, Gaithersburg, Maryland, USA.

18. Hopley D (2016) The evaluation of the potential of Tenebriomolitor, Zophobasmorio, Naophoeta cinerea, Blaptica dubia, Gromphardhina portentosa, Periplaneta americana, Blatta lateralis, Oxyhalao duesta and Hermetia illucens for use in poultry feeds. Stellenbosch University, South Africa.

19. Agbo NW, Madalla N, Jauncey K (2011) Effects of dietary cottonseed meal protein levels on growth and feed utilization of Nile tilapia, Oreochromisniloticus L. J Appl Sci Environ Manage 15(2): 235-239.

20. Oonincx DG, Broekhoven S, Huis A, Loon JJ (2015) Feed conversion, survival and development, and composition of four insect species on diets composed of food by-products. PLoS One 10(12): e0144601.

21. Ravzanaadii N, Kim SH, Choi WH, Hong SJ, Kim NJ (2012) Nutritional value of mealworm, Tenebrio molitor as food source. Int J Indust Entomol 25(1): 93-98.

22. Van Broekhoven S, Oonincx DG, Van Huis A, Van Loon JJ (2015) Growth performance and feed conversion efficiency of three edible mealworm species (Coleoptera: Tenebrionidae) on diets composed of organic byproducts. J Insect Physiol 73: 1-10.

23. Huis A (2013) Potential of insects as food and feed in assuring food security. Annu Rev Entomol 58: 563-583.

24. Bureau DP, Gibson J, El Mowafi A (2002) Review: Use of animal fats in aquaculture feeds. In: Cruz Suárez LE, Ricque Marie D, Tapia Salazar M, Gaxiola Cortés MG, Simoes N (Eds.), Avances en nutriciónacuícola v. Mexico: Memorias del VI Simposium Internacional de Nutrición Acuícola, pp. 487-504.

25. Abel FAS, Adeyemi OA, Oluwole OB, Oladunmoye OO, Ayo Ajasa OY, et al. (2015) Effects of treated banana peel meal on the feed efficiency, digestibility and cost effectiveness of broiler chickens diet. J Vet Sci Anim Husb 3(1): 101.

26. Siyal FA, Wagan R, Bhutto ZA, Tareen MH, Arain MA, et al. (2016) Effect of orange and banana peels on the growth performance of broilers. Advances in Animal and Veterinary Sciences 4(7): 376-380.

27. Józefiak D, Engberg RM (2015) Insects as poultry feed. $20^{\text {th }}$ European Symposium on Poultry Nutrition, Prague, Czech Republic.

28. Lovell $\mathrm{T}$ (1989) The Nutrients. In: Nutrition and Feeding of Fish Springer, Boston, Massachusetts, USA. 
(c) (P) Creative Commons Attribution 4.0 International License

For possible submissions Click Here

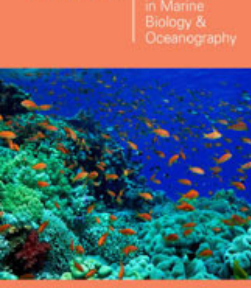

Examines in Marine Biology \& Oceanography

\section{Benefits of Publishing with us}

- High-level peer review and editorial services

- Freely accessible online immediately upon publication

- Authors retain the copyright to their work

- Licensing it under a Creative Commons license

- Visibility through different online platforms 